\title{
Holocene climate variability archived in the Puruogangri ice cap on the central Tibetan Plateau
}

\author{
Lonnie G. THOMPSON, ${ }^{1,2}$ YAO Tandong, ${ }^{3}$ Mary E. DAVIS, ${ }^{1}$ \\ Ellen MOSLEY-THOMPSON, ${ }^{1,4}$ Tracy A. MASHIOTTA, ${ }^{1}$ Ping-Nan LIN, ${ }^{1}$ \\ Vladimir N. MIKHALENKO, ${ }^{5}$ Victor S. ZAGORODNOV ${ }^{1,2}$ \\ ${ }^{1}$ Byrd Polar Research Center, The Ohio State University, 1090 Carmack Road, Columbus, OH 43210-1002, USA \\ E-mail: Thompson.3@osu.edu \\ ${ }^{2}$ Department of Geological Sciences, The Ohio State University, 275 Mendelhall Laboratory, 125 South Oval Mall, \\ Columbus, OH 43210-1308, USA \\ ${ }^{3}$ Institute of Tibetan Plateau Research, Chinese Academy of Sciences, Beijing 10029, China \\ ${ }^{4}$ Department of Geography, The Ohio State University 1036 Derby Hall, 154 North Oval Mall, Columbus, \\ $\mathrm{OH}$ 43210-1361, USA \\ ${ }^{5}$ Institute of Geography, Russian Academy of Sciences, 29 Staromonetny Street, 109017 Moscow, Russia
}

\begin{abstract}
Two ice cores (118.4 and $214.7 \mathrm{~m}$ in length) were collected in 2000 from the Puruogangri ice cap in the center of the Tibetan Plateau (TP) in a joint US-Chinese collaborative project. These cores yield paleoclimatic and environmental records extending through the Middle Holocene, and complement previous ice-core histories from the Dunde and Guliya ice caps in northeast and northwest Tibet, respectively, and Dasuopu glacier in the Himalaya. The high-resolution Puruogangri climate record since $A D 1600$ details regional temperature and moisture variability. The post-1920 period is characterized by above-average annual net balance, contemporaneous with the greatest ${ }^{18} \mathrm{O}$ enrichment of the last 400 years, consistent with the isotopically inferred warming observed in other TP ice-core records. On longer timescales the aerosol history reveals large and abrupt events, one of which is dated $\sim 4.7 \mathrm{kyr}$ BP and occurs close to the time of a drought that extended throughout the tropics and may have been associated with centuries-long weakening of the Asian/Indian/African monsoon system. The Puruogangri climate history, combined with the other TP ice-core records, has the potential to provide valuable information on variations in the strength of the monsoon across the TP during the Holocene.
\end{abstract}

\section{INTRODUCTION}

The Tibetan Plateau (TP) is one of the most imposing topographic features on the Earth's surface. With a mean elevation of $\sim 4.5 \mathrm{~km}$ and an area of $2.5 \times 10^{6} \mathrm{~km}^{2}$, it is onethird the size of the United States. Climate studies there are plagued by the absence of data, particularly in the central region. Since 1987, four long, high-quality ice-core histories have been obtained from the TP by the Ice Core Paleoclimate Research Group at the Byrd Polar Research Center (BPRC): (1) the Dunde ice cap in the Qilian Shan along the northeastern margin, (2) the Guliya ice cap in the Kunlun Shan in the northwest, (3) Dasuopu glacier in the central Himalaya on the southern margin, and (4) the Puruogangri ice cap in the western Tanggula Shan in the center (Fig. 1). The physical and chemical data from these ice cores have contributed significantly to the paleoclimatic history of this region (Thompson and others, 1989, 1990, 1995, 1997, 2000). They have highlighted the complexity of the climate regime here, suggesting that tropical water vapor is an important mechanism forcing global-scale (glacial/interglacial) climate changes and providing evidence that the high plateau may be quite sensitive to the 20th-century warming. Liu and Chen (2000) compiled the annual mean surface temperature anomaly trends from 1961 to 1990 for 178 stations that reveal an increase in the rate of warming per decade with increasing elevation.

The TP is a major heat source for the lower atmosphere, and thus it significantly affects the hemispheric circulation (Flohn, 1965; Luo and Yanai, 1983; Lau and Li, 1984; Yanai and others, 1992; Webster and others, 1998; Hansen and others, 1999). The summer monsoon circulation is driven by the latitudinal temperature gradient produced between the warm Asian land mass and cooler surrounding oceans (Webster, 1987). Precipitation in eastern Asia is controlled primarily by a combination of the resulting thermal and dynamical forcing. Sensible-heat flux over the semi-arid interior western region of the TP, and latent-heat release

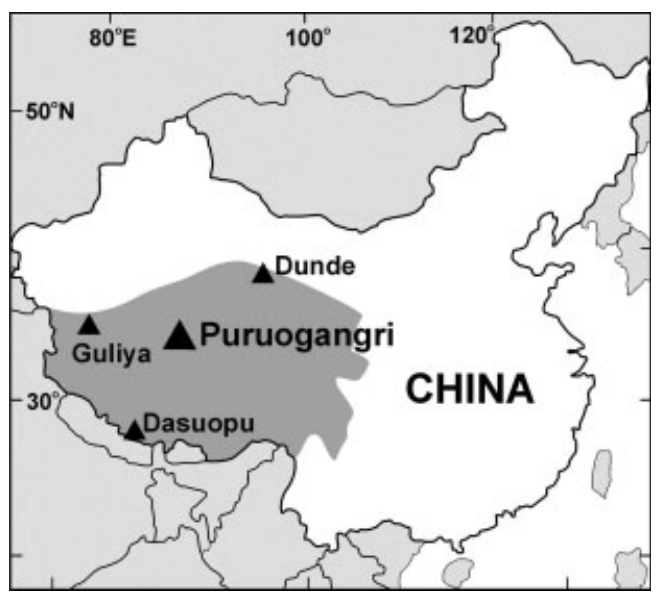

Fig. 1. Map of China showing the outline of the Qinghai-Tibetan Plateau (shaded area) and the location of the Puruogangri ice cap, along with the other sites discussed in the text. 

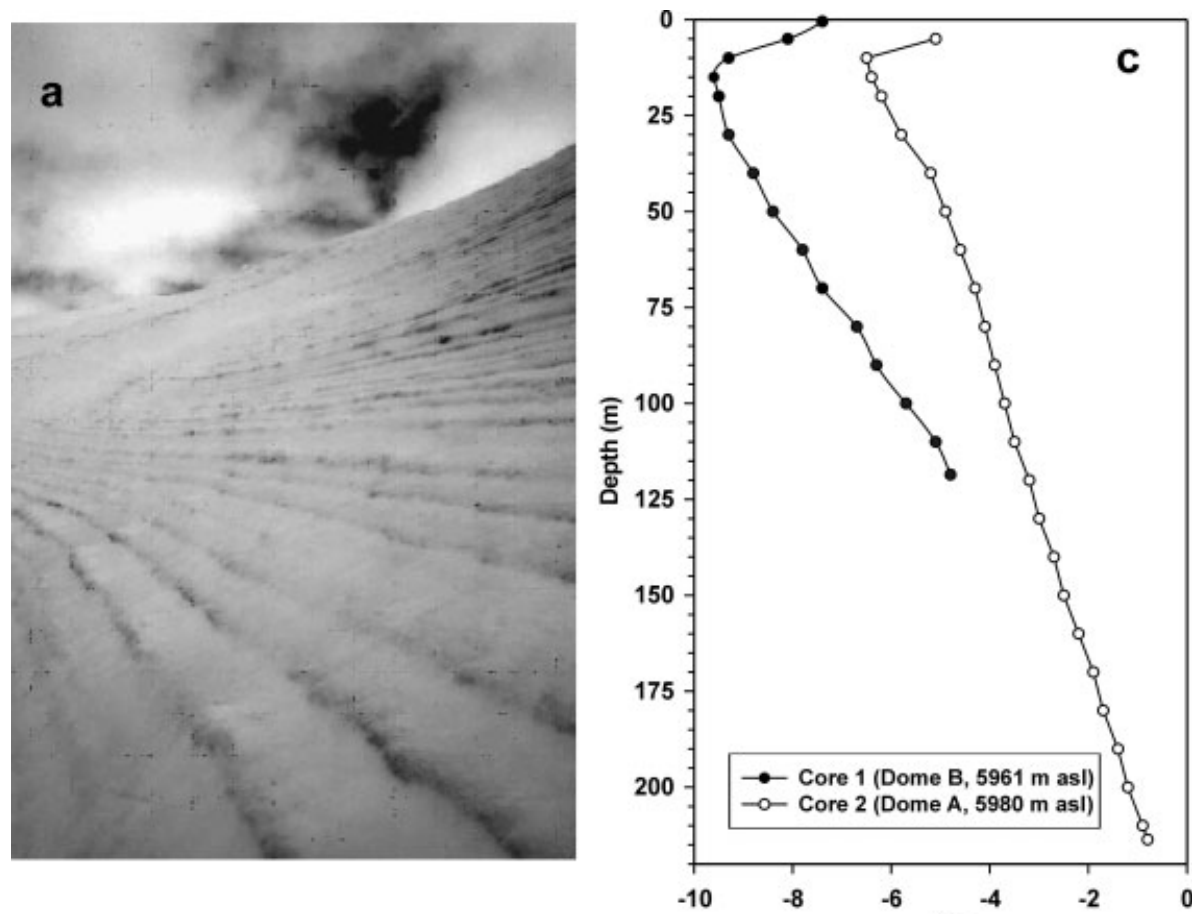

$\left({ }^{\circ} \mathrm{C}\right)$

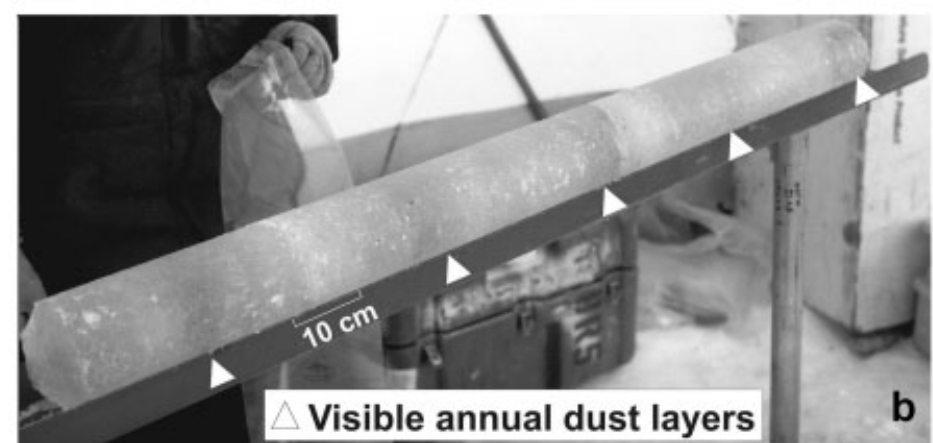

Fig. 2. (a, b) The edge of the Puruogangri ice cap reveals distinctive dust layers (a) that are also visible in the ice cores (b). (c) Borehole temperature profiles for $\mathrm{C} 1$ and $\mathrm{C} 2$.

above the Himalaya provide strong tropospheric heating which maintains the large-scale Asian monsoon circulation. The Puruogangri ice cap $\left(33^{\circ} 55^{\prime} \mathrm{N}, 89^{\circ} 05^{\prime} \mathrm{E} ; 6072 \mathrm{~m}\right.$ a.s.l.) lies directly under the ascending atmospheric motion during the warmest months of June, July and August (Yanai and others, 1992; Webster and others, 1998).

The precipitation over the southern half of the TP is dominated in summer by the southwest Asian monsoon and in winter by westerly cyclonic activity. The strength of the monsoon is determined by a number of forcing mechanisms that operate over a spectrum of timescales. Over the past 10000 years $(10 \mathrm{kyr})$, Northern Hemisphere $(\mathrm{NH})$ insolation has been higher, with correspondingly greater monsoon activity than during the late glacial stage (LGS). During the LGS the reduced differential heating between the Indian Ocean and the Asian continent contributed to the weakening of the summer circulation, producing cooler, drier conditions over Asia and across the southern TP (Clemens and others, 1991; Casal and others, 2004). On shorter timescales, variations in the strength of the southwest Asian monsoon have been explained by changes in boundary conditions, such as increasing tropical sea surface temperatures (Webster and others, 1998), variations in Eurasian snow cover (Barnett and others,
1989), and the El Niño-Southern Oscillation (ENSO) (Rasmusson and Carpenter, 1983).

The TP, including the Himalaya, contains the largest volume of ice outside the polar regions, and the meltwater from its glaciers forms the headwaters of such important rivers as the Yangtze, the Yellow, the Indus, the Brahmaputra and the Ganges. The climate systems that feed or starve these glaciers affect the welfare of nearly two billion people, so it is very important to understand their annual- to decadal-scale variability. The distinct annual dust layers in the Puruogangri ice cores and the chemical composition of the ice offer the potential of an annually resolved climate history for hundreds of years.

\section{MATERIALS AND METHODS}

The geophysical and ice-core drilling program on the Puruogangri ice cap in 2000 was a collaborative effort by the Laboratory of Ice Core and Cold Regions Environment, Cold and Arid Regions Environmental and Engineering Research Institute (LICCRE) and the BPRC. Two cores, core 1 (henceforth $\mathrm{C} 1,118.4 \mathrm{~m}$ long) and core 2 (henceforth $\mathrm{C} 2$, $214.7 \mathrm{~m}$ long) were drilled by BPRC on Domes B and A, respectively, which are $1.35 \mathrm{~km}$ apart. A third core (C3) was 


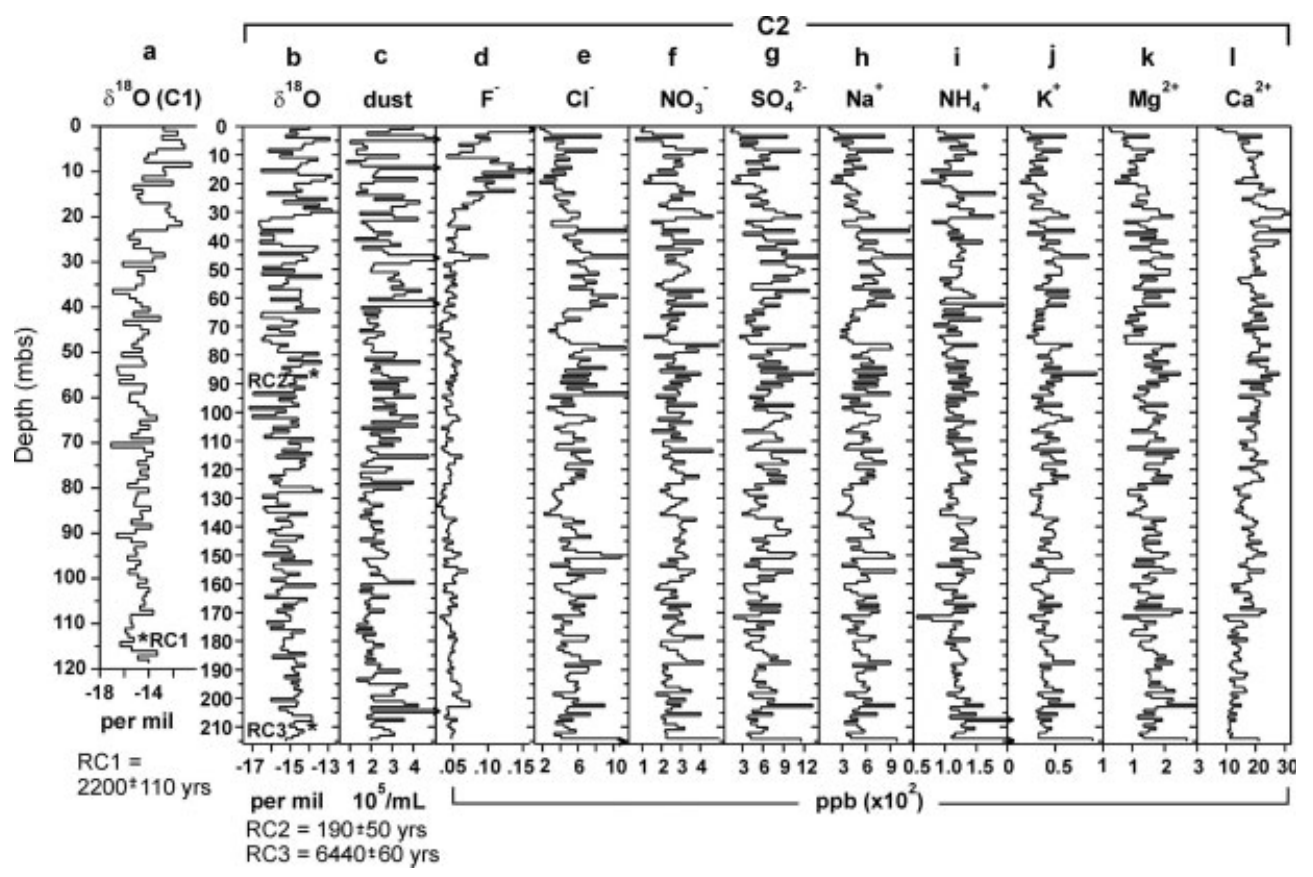

Fig. 3. One-meter averages of (a) $\delta^{18} \mathrm{O}$ for $\mathrm{C} 1\left(118 \mathrm{~m}\right.$ long) and $(\mathrm{b}-\mathrm{l}) \delta^{18} \mathrm{O}$, insoluble dust and soluble ionic species for the longer (215 $\mathrm{m}$ ) $\mathrm{C} 2$. Three calibrated radiocarbon dates are included (bottom), and their depths in the cores are indicated as RC1-RC3.

drilled by LICCRE to $152 \mathrm{~m}$ below the surface (mbs). C1 and C3 were returned whole to their respective institutes, and C2 was split equally between the groups. Annual dust layers are visible along the margin of the ice cap (Fig. 2a), and can also be seen in the ice cores (Fig. 2b). Ice temperatures (Fig. 2c) were $-9.7^{\circ} \mathrm{C}$ at $10 \mathrm{mbs}$ and $-5^{\circ} \mathrm{C}$ at the ice/bedrock contact in the $\mathrm{C} 1$ borehole (5961 ma.s.I.) and $-6^{\circ} \mathrm{C}$ at $10 \mathrm{~m}$ and $-0.9^{\circ} \mathrm{C}$ at the bottom of the $\mathrm{C} 2$ borehole $(5980 \mathrm{~m}$ a.s.I.) that did not reach bedrock.

Cores were recovered using an electromechanical drill with conventional cutters that achieved an average production rate of $\sim 7.0 \mathrm{~m} \mathrm{~h}^{-1}$ down to $125 \mathrm{mbs}$. Below that depth, the core quality was compromised by ice stresses and an increase in ice temperature from $-3.0^{\circ} \mathrm{C}$ to $-0.8^{\circ} \mathrm{C}$. During a typical day, the core quality decreased during the warmest hours (1300-1600 h). As the drilling rates decreased toward the bottom of the $\mathrm{C} 2$ borehole (below $200 \mathrm{mbs}$ ), core sections averaged about $0.4 \mathrm{~m}$ in length. For a full description of the drilling system and core quality control, see Zagorodnov and others (2005).

At BPRC, C1 and C2 were cut into 4114 and 6303 samples, respectively. Both cores are composed of ice throughout (i.e. they lack firn at the top) and were analyzed for stable-isotopic ratios of oxygen $\left(\delta^{18} \mathrm{O}\right)$ and hydrogen $(\delta \mathrm{D})$. Only C2 was analyzed for insoluble dust concentrations and size distributions and for concentrations of major anions $\left(\mathrm{F}^{-}, \mathrm{Cl}^{-}, \mathrm{SO}_{4}{ }^{2-}, \mathrm{NO}_{3}{ }^{-}\right)$and cations $\left(\mathrm{Na}^{+}, \mathrm{K}^{+}\right.$, $\mathrm{NH}_{4}{ }^{+}, \mathrm{Mg}^{2+}, \mathrm{Ca}^{2+}$ ) in a class 100 clean room. Samples were cut at sub-annual resolution until the depth where annual layers were no longer discernible. Stable isotopes were measured using Finnigan Mat Delta Plus mass spectrometers; dust concentrations and size distributions were measured with a Coulter Counter Model TAII; and the ion concentrations were measured with Dionex DX-500 ion chromatographs equipped with A/S 40 auto-samplers. A Tennelec LB 1000 series alpha/beta counter identified the distinct $1962 / 63$ beta $(\beta)$ radioactivity horizon produced by massive Soviet atmospheric thermonuclear testing.
Figure 3 illustrates the $1 \mathrm{~m}$ averages of $\delta^{18} \mathrm{O}$ (for both cores) and the ionic and insoluble dust concentrations for $\mathrm{C} 2$. The highest insoluble and soluble aerosol concentrations in $\mathrm{C} 2$ occur between 35 and $60 \mathrm{~m}$ and between 80 and $125 \mathrm{~m}$, with an interval of low aerosols and $\delta^{18} \mathrm{O}$ in between. $\delta^{18} \mathrm{O}$ variability is relatively uniform in both cores, but increases abruptly at $\sim 30 \mathrm{mbs}$ in $\mathrm{C} 2$ and $\sim 23 \mathrm{mbs}$ in C1, coincident with reduced aerosol concentrations. Calcium concentrations gradually increase from $214.7 \mathrm{mbs}$ up to $35 \mathrm{mbs}$, before decreasing along with the other ions.

\section{TIMESCALE DEVELOPMENT}

\section{The most recent four centuries of the record}

The annually resolved timescale for the upper part of $\mathrm{C} 2$ was developed back to $\mathrm{AD} 1600$ by counting peaks in the concentration of dust particles that are deposited during the late winter/early spring. Figure $4 \mathrm{a}$ and b illustrate $\delta^{18} \mathrm{O}$ and dust concentrations for each sample in the top $20 \mathrm{~m}$ of C2, along with the $1962 / 63 \beta$ radioactivity peak (Fig. 4c) at $14.5 \mathrm{mbs}$. This provides a reference horizon for calibrating the annual dating of the upper part of the record, and confirms that the average annual net balance $\left(A_{n}\right)$ over the most recent 38 years is $382 \mathrm{~mm}$ ice equivalent. Every fifth year is marked (Fig. 4b), showing that, in general, dust peaks are often associated with low $\delta^{18} \mathrm{O}$, consistent with the seasonal $\delta^{18} \mathrm{O}$ distribution in the region of the TP north of (and including) the Tanggula Shan (Araguás-Araguás and others, 1998; Tian and others, 2001) as well as on the Dunde ice cap (Davis and others, 2005). Sublimation at the surface of the glacier may be smoothing the isotopic variations and causing some annual dust layer compaction, which makes layer counting less straightforward than in colder, higher-accumulation regions. Layer thinning with depth is evident by comparing seasonal variations in dust and $\delta^{18} \mathrm{O}$ in the upper $20 \mathrm{~m}$ (Fig. 4a and b) with those in $10 \mathrm{~m}$ of the core from 90 to $100 \mathrm{mbs}$ (Fig. 4d and e). Annual 

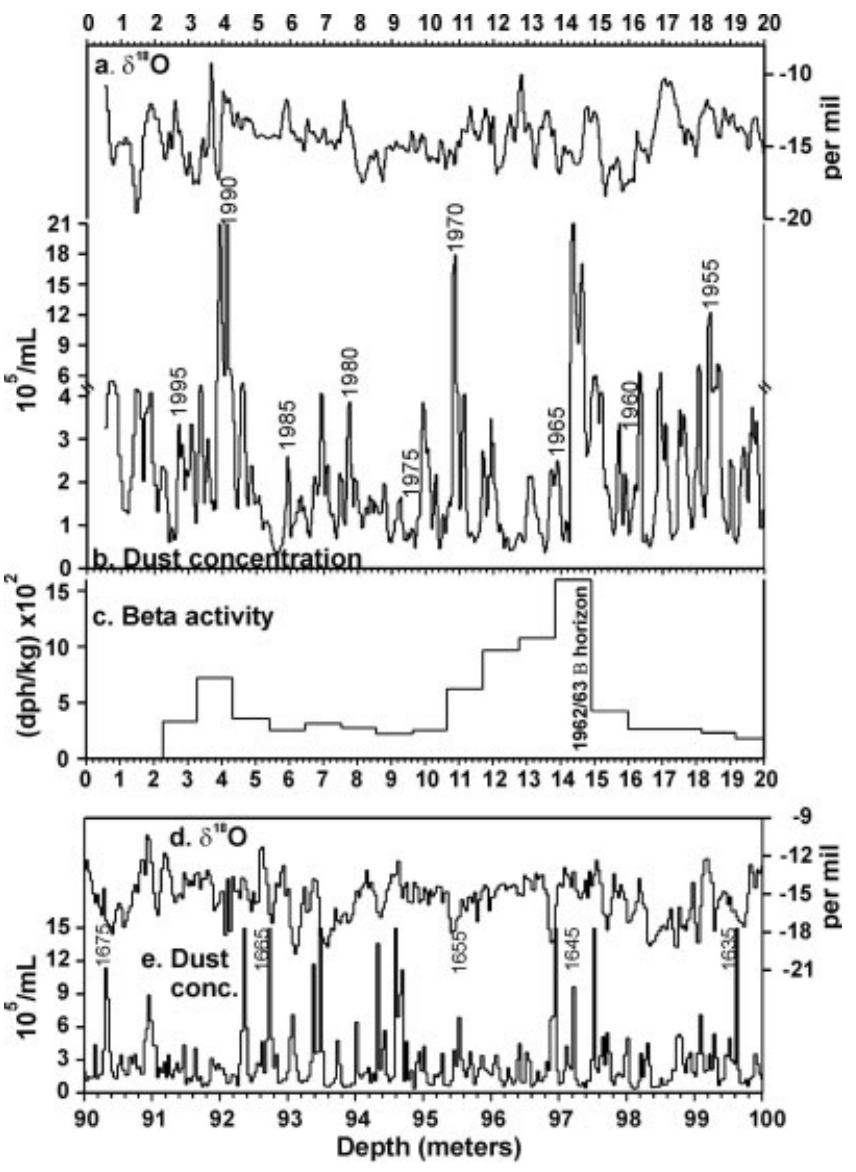

Fig. 4. $(\mathrm{a}, \mathrm{b})$ The $\delta^{18} \mathrm{O}$ and dust concentrations shown as individual samples for the top $20 \mathrm{~m}$ of $\mathrm{C} 2$. The seasonal variations used to date the core are shown from 1955 to 2000 along with the $\beta$ profile (c) that illustrates the radioactivity peak in 1962/63, that resulted from atmospheric thermonuclear testing. $(\mathrm{d}, \mathrm{e})$ The $\delta^{18} \mathrm{O}$ and dust variations from 90 to $100 \mathrm{mbs}$ (AD 1634-76) illustrate annual layer thinning with depth.

dust peaks were counted down to $107.6 \mathrm{mbs}$ (AD 1600), below which annual resolution became problematic due to the increasing rate of thinning. The degree of uncertainty in the timescale increases with depth, from \pm 1 year above the 1962/63 horizon to \pm 15 years at AD 1600 .

To reconstruct the original thicknesses of the annual layers counted in $\mathrm{C} 2$, and thereby produce the $A_{\mathrm{n}}$ record from AD 1600 to 2000, the thinning with depth was estimated. Here a steady-state flow model that takes into account the rapid thinning of layers near a glacier's flow divide (Thompson and others, 1989, 1990) is used for C2. The reconstructed annual layer thickness as a function of depth is given by the relationship

$$
L(z)=b\left(1-\frac{z}{H}\right)^{-p+1},
$$

where $H$ is the length from surface to bedrock, $b$ is the measured thickness of each annual layer, and $z$ is the corresponding ice equivalent depth. Under steady-state conditions, a unique value of the exponent $p$ (a thinning parameter) can be calculated by substituting the depths $\left(z_{1}\right.$ and $z_{2}$ ) of two well-dated horizons at times $T_{1}$ and $T_{2}$ into Equation (2):

$$
T_{2}\left[\left(1-\frac{Z_{1}}{H}\right)^{-p}-1\right]=\mathrm{T}_{1}\left[\left(1-\frac{Z_{2}}{H}\right)^{-p}-1\right] .
$$

For C2 the two time horizons used for the model were $T_{1}=37$ years at $14.5 \mathrm{mbs}$, which is the $\beta$ horizon, and $T_{2}=400$ years at $107.6 \mathrm{mbs}$ obtained from layer counting.

\section{The Holocene timescale development}

The low relief between the top of Puruogangri and the surrounding terrain facilitates deposition of plant fragments on the ice cap; consequently, three such samples were recovered from the cores (see asterisks in Fig. 3). The radiocarbon dates near the bottom of $\mathrm{C} 1$ (RC1) and C2 (RC3) were useful for the development of the longer-term Holocene records. The two-parameter model (Equation (2)) was used to construct a timescale for C2 from $z_{1}=107.6 \mathrm{mbs}$ (corresponding to $T_{1}=400$ years BP) to $z_{2}=210.5 \mathrm{mbs}$, which was radiocarbon-dated at $6440 \pm 160$ years (calibrated) before $\operatorname{AD} 1950$ ( $T_{2}$ is 6490 years BP). The model unrealistically assumes a constant accumulation rate over the modeled timescales. When the time and depth values for the two horizons were inserted into Equation (2), the exponent $p$ was calculated to be 0.54 . The model was then solved for $T_{2}$ at various values of $z_{2}$, using $p=0.54$, $T_{1}=400$ years BP and $z_{1}=107.6 \mathrm{mbs}$. The resulting age/ depth relationship is shown in Figure $5 \mathrm{a}$. As the oldest ${ }^{14} \mathrm{C}$ date (RC3 in C2) is $4 \mathrm{~m}$ above the core bottom, there is no way to constrain the model below $210.5 \mathrm{~m}$, so the dating is extrapolated only another $50 \mathrm{~cm}$ further down-core to 7000 years BP.

Since both the layer-counted date of 400 years BP at $107.6 \mathrm{mbs}$ and the radiocarbon date of 6490 years BP at 210.50 mbs contain uncertainty ranges $( \pm 15$ and \pm 60 years, respectively), the two-parameter model was used to determine the range of errors throughout the Holocene timescale. Figure 5a (inset) illustrates how the range of error calculated by the model changes from \pm 15 years at 400 years BP to \pm 68 years at $\sim 4630$ years $\mathrm{BP}$, and then decreases to the radiocarbon-constrained error of \pm 60 years at 6490 years BP.

The timescale for $\mathrm{C} 1$ was calculated in the same manner; the upper horizon $\left(z_{1}=23.07 \mathrm{mbs}\right.$ at $\mathrm{T}_{1} 84$ years BP) was transferred from the annually dated part of $\mathrm{C} 2$ by $\delta^{18} \mathrm{O}$ curve matching. The lower horizon at $114.0 \mathrm{mbs}$ was radiocarbon dated at $2200 \pm 110$ years before AD 1950. With the value of $p$ calculated from these two points as 0.35 , the resulting age/ depth relationship with the model-calculated error curve is shown in Figure 5b.

\section{THE PURUOGANGRI CLIMATE RECORD SINCE AD 1600}

The 5 year averages of $\delta^{18} \mathrm{O}$ from $\mathrm{C} 1$ and $\mathrm{C} 2$ are shown in Figure $6 \mathrm{a}$ and $\mathrm{b}$, along with the $\mathrm{C} 2$ records of reconstructed net accumulation $\left(A_{\mathrm{n}}\right)$ (Fig. 6c), dust (Fig. 6d) and the ion concentrations of soluble aerosols (Fig. 6e-m) for the last four centuries (AD 1600-2000). Except for fluoride (Fig. 6e), the soluble aerosol concentrations are in good agreement with each other. Both the $\delta^{18} \mathrm{O}$ records capture similar decadal- to centennial-scale variability, although the 20th-century ${ }^{18} \mathrm{O}$ enrichment is more pronounced in $\mathrm{C} 1$. Previous research in the northern region of the TP indicates that it is reasonable to consider $\delta^{18} \mathrm{O}$ as a proxy for temperature (Yao and others, 1996; Thompson and others, 2003; Thompson and Davis, 2005).

Four major periods (marked in Fig. 6) are identified: period 1 from 1600 to $\sim 1730$ was slightly warmer and much wetter than the 400 year average as suggested by above-average 

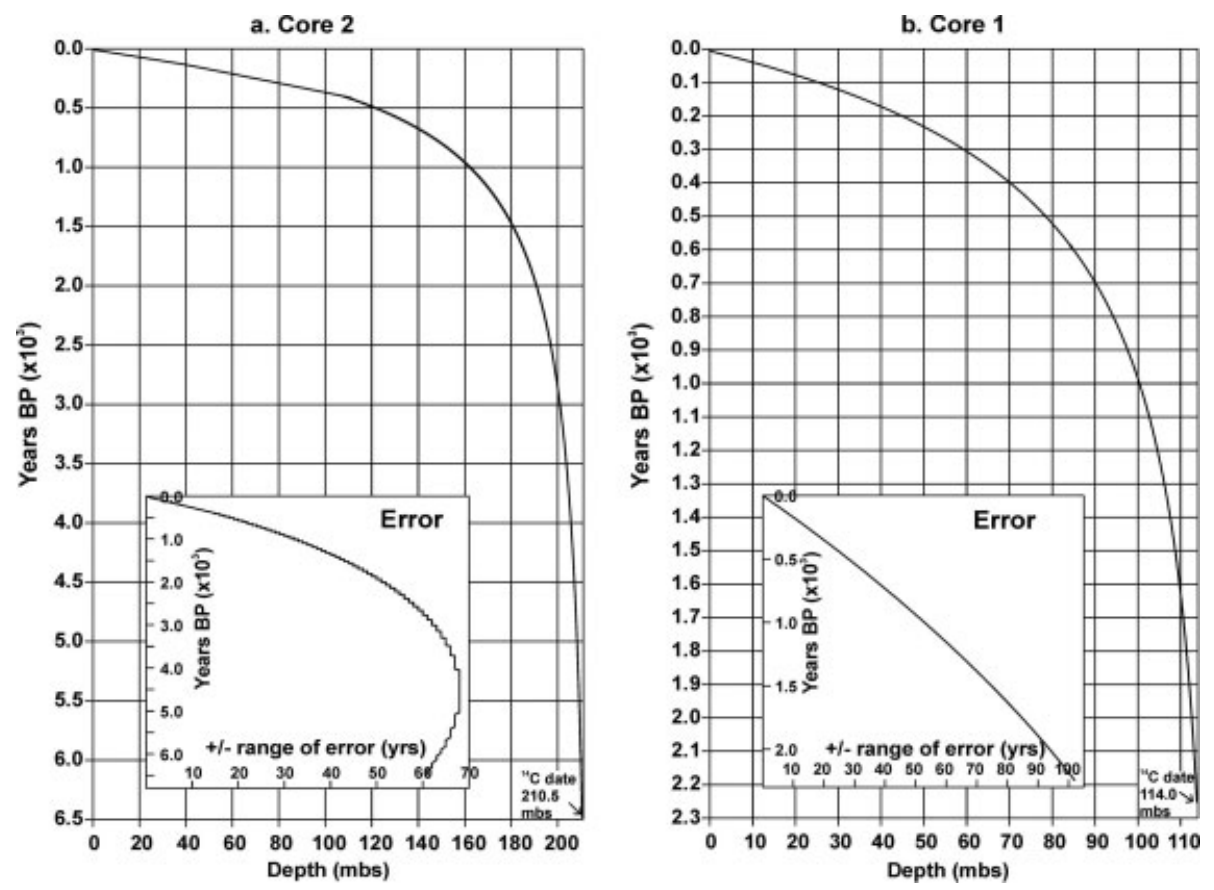

Fig. 5. Age/depth relationships as calculated by the two-parameter model (Equation (2)) for (a) C2 down to 7 kyr BP and (b) C1 down to $2.3 \mathrm{kyr}$ BP. The range of errors as computed by the model for each core, based on the error ranges of the cores' respective ${ }^{14} \mathrm{C}$ dates (as depicted), are shown as insets.

$\delta^{18} \mathrm{O}$ and $A_{\mathrm{n}}$; period 2 from 1730 to 1780 was cool (lower $\delta^{18} \mathrm{O}$ ) but wet; period 3 (1780 to $\sim 1915$ ) had intermittent $\mathrm{cool} /$ warm and mostly dry conditions; and period $4(\sim 1915$ to the present) was wetter and warmer. Insoluble dust (henceforth dust) concentrations were lower in periods 1 and 2, but increased sharply after a large, abrupt event in 1790. This complements the $A_{\mathrm{n}}$ record which implies higher accumulation rates during periods 1 and 2, followed by below-average rates beginning around 1775 , just prior to the increase in dust deposition. Period 1 was unusual, in that the soluble aerosol concentrations were above average at a time when $A_{n}$ was also high but dust was low. This was not consistent with either the relationship (high $A_{\mathrm{n}}$ and low aerosols) found in periods 2 and 4, nor the reverse relationship (low $A_{\mathrm{n}}$ and high aerosols) found in period 3, the end of the last neoglacial period commonly called the 'Little Ice Age' (LIA).

The Puruogangri $A_{\mathrm{n}}$ record is similar to those from two previous northern Tibet ice-core records, Dunde at $38^{\circ} \mathrm{N}$ (Thompson, 1992) and Guliya at $35^{\circ} \mathrm{N}$ (Thompson and others, 1995) (Fig. 1), but opposite to that in Dasuopu glacier at $28^{\circ} \mathrm{N}$ (Thompson and others, 2000; Davis and Thompson, 2004; Davis and others, 2005). At the northern core sites, $A_{\mathrm{n}}$ was above average before 1800, below

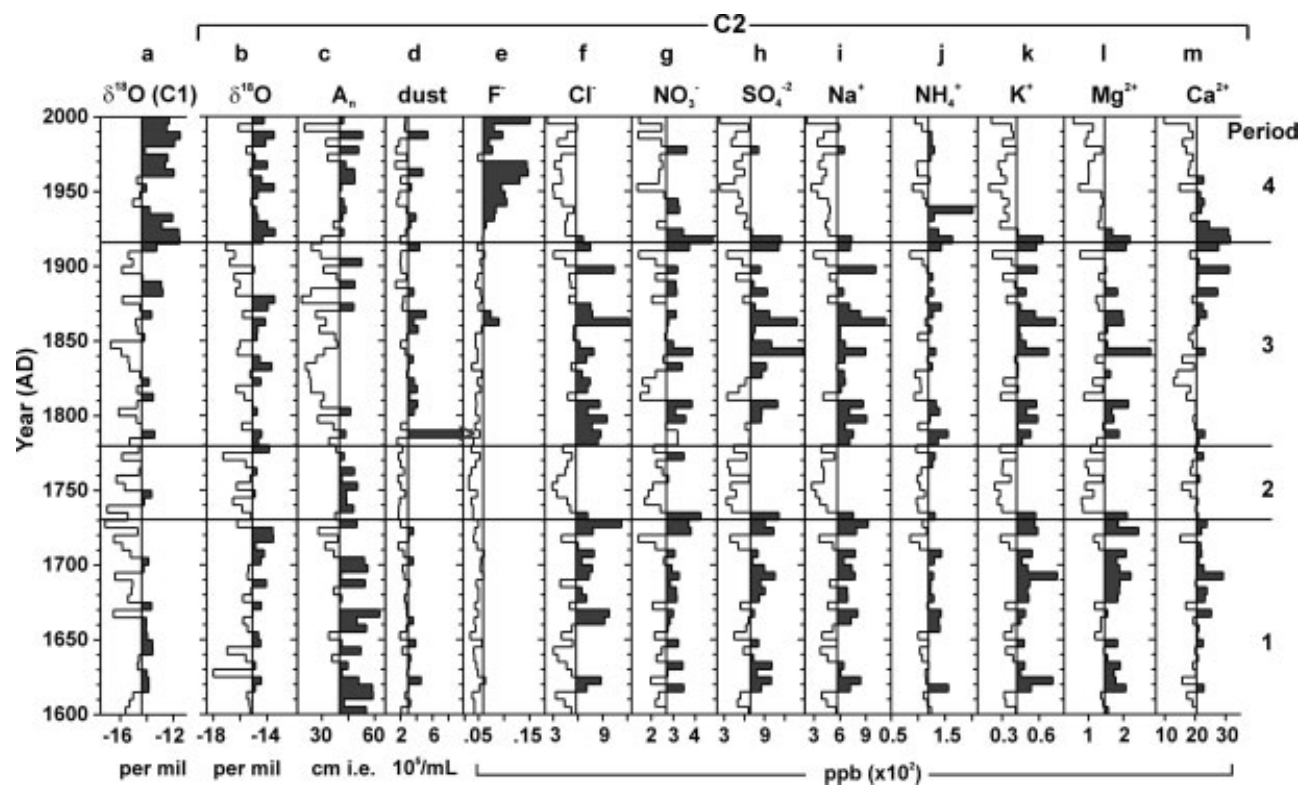

Fig. 6. The 5 year averages for the last 400 years shown for $\delta^{18} \mathrm{O}$ in both $\mathrm{C} 1$ and $\mathrm{C} 2$, along with the concentrations of insoluble dust and soluble species from $\mathrm{C} 2$. The four climatic periods (1-4) discussed in the text are marked. 


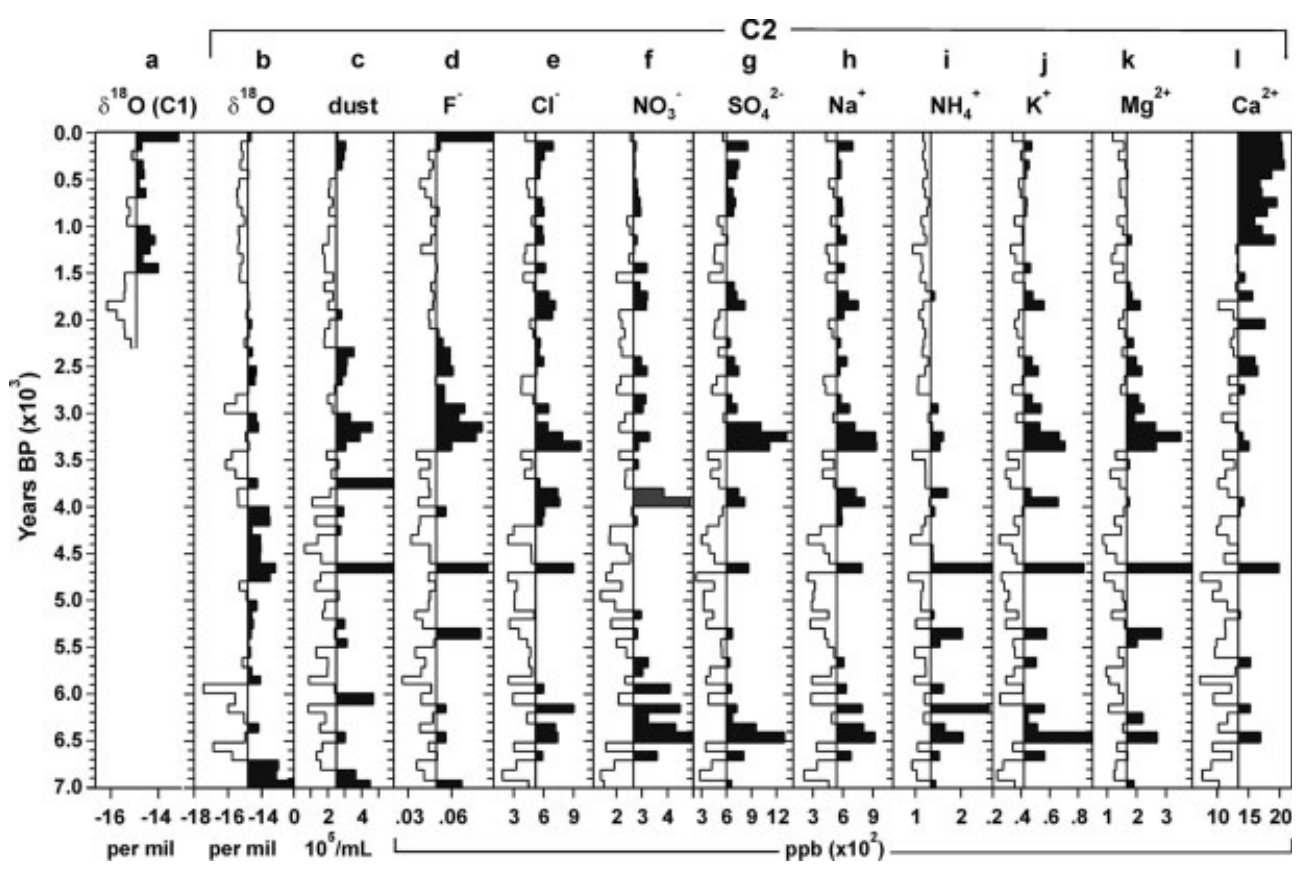

Fig. 7. The 100 year averages of (a) $\delta^{18} \mathrm{O}$ for $\mathrm{C} 1$ for the last 2300 years and (b) $\delta^{18} \mathrm{O}$, (c) dust and (d-l) ion concentrations for $\mathrm{C} 2$ for the last 7000 years.

average from $\sim 1800$ to the late 19 th to early 20 th centuries, and then above average over most of the 20th century. The resemblance among the low-frequency $A_{\mathrm{n}}$ records from the three northern ice cores, and their anti-phase relationship with the southernmost record from the Himalaya, suggests a climatic dichotomy across the TP. The region north of $\sim 33^{\circ} \mathrm{N}$ may be more strongly dominated by westerly continental air masses than the southern region, which is more strongly influenced by tropical monsoon circulation. These relationships, however, may have varied through time (Davis and others, 2005).

An abrupt warming (inferred from higher $\delta^{18} \mathrm{O}$ values) occurred between 1910 and 1920 (Fig 6a and b) and was accompanied by higher $A_{\mathrm{n}}$ (Fig. 6c) and lower soluble aerosol concentrations (except $\mathrm{F}^{-}$), suggesting a transition to a warmer, wetter climate. Both cores show post-1920 enrichment in ${ }^{18} \mathrm{O}$, although this is more prominent in $\mathrm{C} 1$ than in $\mathrm{C} 2$. This difference may be attributed to postdepositional processes such as differences in ice flow at depth on the adjacent domes of the ice cap. Fluoride concentration began to increase markedly above its 400 year baseline around 1930 (Fig. 6e), but whether this was related to the changing climate conditions is unknown. With the recent warming of the TP, many glaciers are now undergoing wasting and deterioration of their surfaces, and on Puruogangri the trend in net balance has been decreasing over the last few decades (Fig. 6c). This ice cap, like Guliya, lacks an upper firn layer and is mainly ice to the surface, perhaps due to melting caused by increasing air temperatures.

\section{THE PURUOGANGRI RECORD OVER THE LAST 7000 YEARS}

The last 400 years of the Puruogangri ice-core record can be viewed from a much longer perspective in Figure 7, which depicts the chemical and physical species as 100 year averages. This millennial-scale view shows more variability in all the parameters (except $\mathrm{Ca}^{2+}$ ) before $\sim 2.5 \mathrm{kyr}$ BP than after. Dust and ion concentration peaks occur in the record at $6.5,4.7,3.8$ and $3.3 \mathrm{kyr} \mathrm{BP}$, although these events are not always uniformly expressed in all the parameters. The aerosol peaks are not associated with any particular trend in $\delta^{18} \mathrm{O}$, and increases in soluble and insoluble dust were not always consistently associated with warm or cold climates. Calcium (Fig. 7l) also shows high concentrations during these four events; however, Holocene concentrations rose gradually until an abrupt increase $\sim 1.2 \mathrm{kyr} B \mathrm{~B}$, after which it remained at elevated levels to the present.

Since 7 kyr BP, precipitation on Puruogangri has gradually become more depleted in ${ }^{18} \mathrm{O}$ as the isotopic record from C2 suggests (Fig. 7b), but both $\mathrm{C} 2$ and $\mathrm{C} 1$ (Fig. 7a) show enrichment during the last 100 years. As in the 400 year time series discussed above, the enrichment is more pronounced in C1. Likewise, $\mathrm{F}^{-}$also abruptly increased to nearly twice the average Holocene levels in the most recent century, unlike the other aerosols.

\section{DISCUSSION}

\section{The recent record}

The records from the Puruogangri ice cap help fill the information gap for the middle of the TP, where highresolution histories of climatic and environmental change are scarce. It lies close to the boundary between the monsoon-dominated south and the continental westerlydominated north. In winter the climate is influenced by westerly storm tracks originating in the Arctic and North Atlantic. The seasonal relationship between high/low mineral dust concentration and low/high $\delta^{18} \mathrm{O}$ is similar to that in the Dunde ice cores to the north, and opposite that on Dasuopu in the Himalaya, suggesting that Puruogangri is influenced more by the continental climatic processes than by the monsoon, although summer snow is likely recycled through convective activity driven by the heated highaltitude surface. 
Over the last four centuries no significant relationship is evident between temperature and precipitation around this ice sheet. Likewise, the ionic species do not vary inversely with either $\delta^{18} \mathrm{O}$ or $A_{\mathrm{n}}$ in a consistent manner. This may suggest that either the provenance of the soluble aerosols changed before 1730 when the western Tanggula Shan experienced greater snowfall, or average middle tropospheric circulation strength and/or patterns changed. The concentrations of the ionic constituents of salts (e.g. $\mathrm{Cl}^{-}$, $\mathrm{SO}_{4}{ }^{2-}, \mathrm{Na}^{+}$and $\mathrm{K}^{+}$), which may have been derived from nearby lake beds, have similarly varied from one period to another. These were more abundant during period 3, or the end of the LIA, when the local climate was cold and dry, and were less abundant during the higher-accumulation conditions of periods 2 and 4.

Dasuopu glacier records a major historically documented monsoon failure that produced devastating droughts in India from 1790 to 1796 (Lamb, 1982) and is believed to have been a response to a period of severe El Niño events (Quinn, 1992). It is recorded in the Himalayan glacier by sharp increases in dust and anion concentrations, especially $\mathrm{Cl}^{-}$ (Thompson and others, 2000). In the Puruogangri C2 dust time series the strongest peak of the 400 year record is seen close to that time (Fig. $6 \mathrm{~d}$ ). If this is the same event, its temporal offset in the two cores may be due to timescale uncertainties, which range up to \pm 10 years at this depth in C2. Interestingly, dust concentrations in both Dasuopu and Puruogangri remain higher thereafter. While the concentration in Dasuopu continued to increase toward the top of the core as the $A_{\mathrm{n}}$ decreased, dust concentrations in Puruogangri have slowly decreased as $A_{\mathrm{n}}$ has increased.

The combination of higher temperatures, as seen in the isotopic records of C2 and especially C1 (Fig. 6a and b), and wetter climate since $\sim 1920$ is unprecedented in the last four centuries in the Puruogangri record. Similar trends in recent warming, especially after 1920, have been noted in circumArctic climate records (Overpeck and others, 1997). This may be significant, since linkages between the Arctic and monsoon-dominated regions of Asia have been observed in several studies (e.g. Gupta and others, 2003; Wang and others, 2003; Davis and Thompson, 2004).

\section{CLIMATIC AND ENVIRONMENTAL VARIATIONS SINCE THE MIDDLE HOLOCENE}

The general trend in $\delta^{18} \mathrm{O}$ in $\mathrm{C} 2$ since the Early Holocene (Fig. 7b) is consistent with the Northern Hemisphere summer insolation curve, suggesting that the stable isotopes reflect the gradual cooling since the 'climatic optimum' of the Early Holocene until the onset of the recent warming over much of the TP. Since the Tanggula Shan lie close to a climate regime boundary (Araguás-Araguás and others, 1998; Tian and others, 2001), their glaciers may be well positioned to record the southward migration of the summer monsoon trough from its northernmost position at maximum $\mathrm{NH}$ summer insolation intensity.

A prominent Mid-Holocene event ( $\sim 4.7 \mathrm{kyr} B \mathrm{BP})$ is recorded by very high concentrations in dust (Fig. 7c) and in nearly all soluble aerosols except $\mathrm{NO}_{3}{ }^{-}$(Fig. 7f). It is difficult to determine from this record whether this reflects an arid interval in the center of the TP since $A_{n}$ cannot be reconstructed at this depth and, as Figure 6 illustrates, high ion concentrations can occur coincidentally with high $A_{\mathrm{n}}$. However, this peak occurs near the time of a well-studied climatic disruption, most likely a drought, that has been observed in many climate proxy records from eastern China (Morrill and others, 2003; Wang and others, 2005), Tibet (Gasse and others, 1996), the Indus valley (Staubwasser and others, 2003), the Middle East (Weiss and others, 1993; BarMatthews and others, 1999; Cullen and others, 2000) and northern and eastern Africa (Gasse, 2000; Thompson and others, 2002). Failure of the Asian/Indian/African monsoon is strongly implicated as the driver of this event, which lasted several decades to centuries and began and ended abruptly. If this Middle Holocene aridity event is recorded in Puruogangri, it demonstrates that its effects penetrated deeply into the TP.

Calcium concentrations (Fig. 7l) have increased over the Late Holocene since $3.5 \mathrm{kyr} \mathrm{BP}$, while dust and $\delta^{18} \mathrm{O}$ (Fig. 7a and $b$ ), and to a lesser extent other ion species, have all decreased gradually. Analyses of carbonates from the Bangong Co basin, located south of the Kunlun Shan and directly west of Puruogangri, show very low $\delta^{18} \mathrm{O}$ values in the Early Holocene, which become more ${ }^{18} \mathrm{O}$-enriched towards the present. The lacustrine isotope record resembles the ice-core calcium record (Fig. 7l) in which $\mathrm{Ca}^{2+}$ levels increase slowly until $\sim 1.2 \mathrm{kyrBP}$, then rise abruptly and remain high to the present (Fontes and others, 1996). Likewise, at the horizon dated $\sim 1.3 \mathrm{kyr}$ BP in the lake core the abundance of aragonite abruptly increases at the expense of calcite, while the $\delta^{18} \mathrm{O}$ of the carbonates abruptly decreases (Gasse and others, 1996), both signaling the onset of more arid and possibly windier conditions. The Puruogangri ice cap is surrounded by sand dunes composed of carbonates, and the $\mathrm{Ca}^{2+}$ levels are among the highest ever measured in an ice core. Thus, the calcium source is probably more local than that for the ions that compose other salts, and its abundance may vary in response to changes in the immediate environment. Thus, some of the chemical species in Puruogangri may reflect climatic changes in more distant locations, while others record more proximal climate variations.

\section{THE PURUOGANGRI RECORD IN THE CONTEXT OF OTHER TP ICE-CORE RECORDS}

To illustrate larger temporal- and spatial-scale changes from the other ice-core sites across the TP, Figure 8 compares the decadal averages of $\delta^{18}$ O over the last 2000 years for Dunde, Guliya, the two new Puruogangri cores and Dasuopu (see Fig. 1 for locations). Since $70-80 \%$ of the snowfall over Tibet arrives during the Northern Hemisphere summer, the isotopic mean compositions in the ice cores represent mainly the summer months. These $\delta^{18} \mathrm{O}$ records show that Dasuopu, the highest site $(7200 \mathrm{~m}$ a.s.l.), has the lowest isotopic average $(-20.32 \%)$, while the lowest site, Dunde (5325 $\mathrm{m}$ a.s.l.), has the highest isotopic average $(-10.77 \%$ ). The average for Guliya at $6200 \mathrm{~m}$ a.s.l. is $-14.96 \%$. The cores from Puruogangri (6000 m a.s.I.), which is close to Guliya in elevation, have average isotopic values of $-15.13 \%$ for C2 and $-14.85 \%$ for $\mathrm{C} 1$. The varying lengths of the records reflect the ages down to which we have confidence in the decadal-timescale reconstructions.

These time series of isotopic variations reflect the variability that exists across the TP. The timescales, based on combinations of annual-layer counting and flow modeling, are believed to be reasonably accurate at low (centennial-scale) frequencies. However, they are subject 


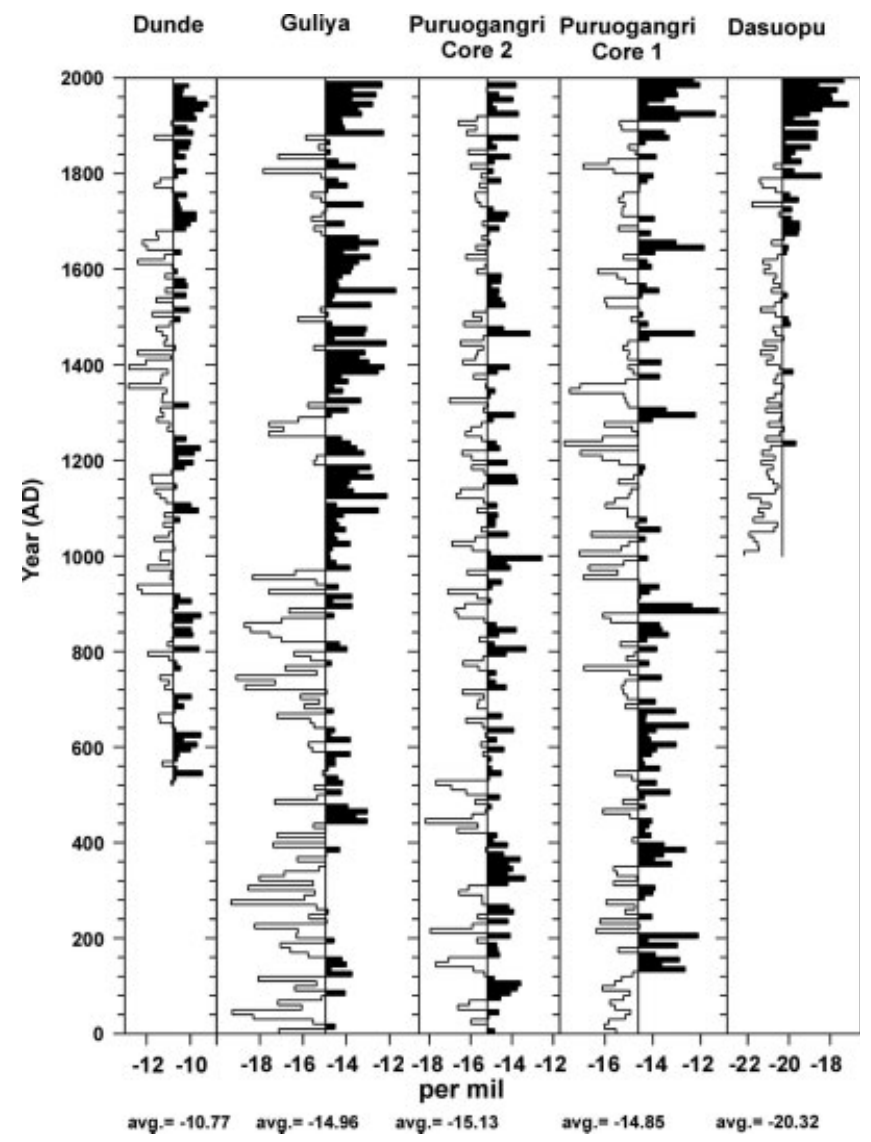

Fig. 8. Comparison of the 10 year $\delta^{18} \mathrm{O}$ averages from the four icecore sites across the TP for the last 2000 years.

to refinement as more datable horizons are identified. Viewed together, there is not a clear, consistent signal marking either the 'Medieval Warm Period' from AD $\sim 1100$ to 1300 , or the LIA from $A D \sim 1400$ to 1900 . With the exception of Puruogangri C2, the records show the abrupt onset of the recent warming in the early 20th century, suggesting that this trend is widespread throughout high Asia regardless of the regional level of effective moisture. While the exact factors driving the ${ }^{18} \mathrm{O}$ enrichment in the 20th century may be debated, it is clear that this enrichment is common to all four sites, albeit to varying degrees. This coherence is unusual within the 2000 year perspective provided by these records.

\section{CONCLUSIONS}

The records of climatic and environmental variation from the Puruogangri ice cap contribute to ongoing efforts to reconstruct the temporally and spatially complex climate history of the TP over millennial to annual timescales. The differences in the $\delta^{18} \mathrm{O}$ record from the central TP since the Middle Holocene compared with those from the margins suggest that the boundary between the monsoon- and continental-climate regimes may have migrated in the past, partially in response to the intensity of Northern Hemisphere summer insolation. Despite differences over much of their histories, Puruogangri, like Dunde, Guliya and Dasuopu, demonstrates an unambiguous, abrupt warming that began in the early 20th century and continues today. This has ramifications for glacier health and the future of water resources in those areas of Asia with several billion inhabitants who rely on the rivers and streams that rise from the rapidly receding glaciers of the TP.

\section{ACKNOWLEDGEMENTS}

The authors thank the participants in the Puruogangri 1999 and 2000 field programs. We also acknowledge T. Guilderson of Lawrence Livermore National Laboratory, Livermore, CA, USA, for providing radiocarbon dates. We appreciate the valuable comments of two anonymous reviewers and our editor, M. Bender. The fieldwork was funded by The Ohio State University, and the laboratory analyses and interpretation were funded by the US National Science Foundation's Earth System History Program (NSF-ATM0117113). This is Byrd Polar Research Center publication No. 1324.

\section{REFERENCES}

Araguás-Araguás, L., K. Froelich and K. Rozanski. 1998. Stable isotope composition of precipitation over southeast Asia. J. Geophys. Res., 103(D22), 28,721-28,742.

Bar-Matthews, M., A. Ayalon, A. Kaufman and G.J. Wasserburg. 1999. The eastern Mediterranean palaeoclimate as a reflection of regional events: Soreq Cave, Israel. Earth Planet Sci. Lett., 166, 85-95.

Barnett, T.P., L. Dümenil, U. Schlese, E. Roeckner and M. Latif. 1989. The effect of Eurasian snow cover on regional and global climate variations. J. Atmos. Sci., 46(5), 661-685.

Casal, T.G.D., J.E. Kutzbach and L.G. Thompson. 2004. Present and past ice-sheet mass balance simulations for Greenland and the Tibetan Plateau. Climate Dyn., 23(3-4), 407-425.

Clemens, S., W. Prell, D. Murray, G.B. Shimmield and G. Weedon. 1991. Forcing mechanisms of the Indian Ocean monsoon. Nature, 353(6346), 720-725.

Cullen, H.M., P.B. deMenocal, S. Hemming and G. Hemming. 2000. Climate change and the collapse of the Akkadian empire: evidence from the deep sea. Geology, 28(4), 379-382.

Davis, M.E. and L.G. Thompson. 2004. Four centuries of climatic variation across the Tibetan Plateau from ice-core accumulation and $\delta{ }^{18} \mathrm{O}$ records. In Cecil, L.D., J.R. Green and L.G. Thompson, eds. Earth paleoenvironments: records preserved in mid-and low-latitude glaciers. Dordrecht, Kluwer, 145-162.

Davis, M.E., L.G. Thompson, T. Yao and N. Wang. 2005. Forcing of the Asian monsoon on the Tibetan Plateau: evidence from highresolution ice core and tropical coral records. J. Geophys. Res., 110(D4), D04101. (10.1029/2004JD004933.)

Flohn, H. 1965. Thermal effects of the Tibetan Plateau during the Asian monsoon season. Aust. Meteorol. Mag., 49, 55-57.

Fontes, J.C., F. Gasse and E. Gilbert. 1996. Holocene environmental changes in Lake Bangong basin (Western Tibet). Part I: Chronology and stable isotopes of carbonates of a Holocene lacustrine core. Palaeogeogr., Palaeoclimatol., Palaeoecol., 120, 25-47.

Gasse, F. 2000. Hydrological changes in the African tropics since the Last Glacial Maximum. Quat. Sci. Rev., 19(1-5), 189-211.

Gasse, F., J.C. Fontes, E. van Campo and K. Wei. 1996. Holocene environmental changes in Lake Bangong basin (Western Tibet). Part 4: Discussion and conclusions. Palaeogeogr., Palaeoclimatol., Palaeoecol., 120, 79-92.

Gupta, A.K., D.M. Anderson and J.T. Overpeck. 2003. Abrupt changes in the Asian southwest monsoon during the Holocene and their links to the North Atlantic Ocean. Nature, 421(6921), 354-357.

Hansen, J., R. Ruedy, J. Glascoe and M. Sato. 1999. GISS analysis of surface temperature change. J. Geophys. Res., 104(D24), 30,997-31,022.

Lamb, H.H. 1982. Climate, history and the modern world. London and New York, Methuen \& Co. Ltd. 
Lau, K.-M. and M.-T. Li. 1984. The monsoon of East Asia and its global associations - a survey. Bull. Amer. Meteorol. Soc., 65, 114-125.

Liu, X. and B. Chen. 2000. Climatic warming in the Tibetan Plateau during recent decades. Int. J. Climatol., 20(14), 1729-1742.

Luo, H. and M. Yanai. 1983. The large-scale circulation and heat sources over the Tibetan Plateau and surrounding areas during the early summer of 1979. Part I: Precipitation and kinematic analysis. Mon. Weather Rev. 111, 922-944.

Morrill, C., J.T. Overpeck and J.E. Cole. 2003. A synthesis of abrupt changes in the Asian summer monsoon since the last deglaciation. Holocene, 13(4), 465-476.

Overpeck, J. and 17 others. 1997. Arctic environmental change of the last four centuries. Science, 278(5341), 1251-1256.

Quinn, W.H. 1992. A study of Southern Oscillation-related climatic activity for A.D. 622-1990 incorporating Nile River flood data. In Diaz, H.F. and V. Markgraf, eds. El Niño: historical and paleoclimatic aspects of the Southern Oscillation. Cambridge, Cambridge University Press, 119-149.

Rasmusson, E.M. and T.H. Carpenter. 1983. The relationship between eastern equatorial Pacific Sea surface temperatures and rainfall over India and Sri Lanka. Mon. Weather Rev. 111, 517-528.

Staubwasser, M., F. Sirocko, P.M. Grootes and M. Segl. 2003. Climate change at the $4.2 \mathrm{ka} \mathrm{BP}$ termination of the Indus valley civilization and Holocene south Asian monsoon variability. Geophys. Res. Lett., 30(8), 1425. (10.1029/2002GL016822.)

Thompson, L.G. 1992. Ice core evidence from Peru and China. In Bradley, R.S. and P.D. Jones, eds. Climate since A.D. 1500. London and New York, Routledge, 517-548.

Thompson, L.G. and M.E. Davis. 2005. Stable isotopes through the Holocene as recorded in low-latitude, high-altitude ice cores. In Aggarwal, P.D., J.R. Gat and K.F.O. Froehlich, eds. Isotopes in the water cycle. Dordrecht, Springer, 321-340.

Thompson, L.G. and 9 others. 1989. Holocene-Late Pleistocene climatic ice core records from Qinghai-Tibetan Plateau. Science, 246(4929), 474-477.

Thompson, L.G. and 9 others. 1990. Glacial stage ice-core records from the subtropical Dunde Ice Cap, China. Ann. Glaciol., 14, 288-297.

Thompson, L.G. and 6 others. 1995. A 1000 year climatic ice-core record from the Guliya ice cap, China: its relationship to global climate variability. Ann. Glaciol., 21, 175-181.
Thompson, L.G. and 9 others. 1997. Tropical climate instability: the last glacial cycle from a Qinghai-Tibetan ice core. Science, 276(5320), 1821-1825.

Thompson, L.G., T. Yao, E. Mosley-Thompson, M.E. Davis, K.A. Henderson and P. Lin. 2000. A high-resolution millennial record of the south Asian monsoon from Himalayan ice cores. Science, 289(5486), 1916-1919.

Thompson, L.G. and 10 others. 2002. Kilimanjaro ice core records: evidence for Holocene climate change in Tropical Africa. Science, 298(5593), 589-593.

Thompson, L.G., E. Mosley-Thompson, M.E. Davis, P.N. Lin, K. Henderson and T.A. Mashiotta. 2003. Tropical glacier and ice core evidence of climate change on annual to millennial timescales. Climatic Change, 59(1-2), 137-155.

Tian, L., V. Masson-Delmotte, M. Stievenard, T. Yao and J. Jouzel. 2001. Tibetan Plateau summer monsoon northward extent revealed by measurements of water stable isotopes. J. Geophys. Res., 106(D22), 28,081-28,088.

Wang, N., L.G. Thompson, M.E. Davis, E. Mosley-Thompson, T. Yao and J. Pu. 2003. Influence of variations in NAO and SO on air temperature over the northern Tibetan Plateau as recorded by $\delta^{18} \mathrm{O}$ in the Malan ice core. Geophys. Res. Lett., 30(22), 2167. (10.1029/2003GL018188.)

Wang, Y. and 9 others. 2005. The Holocene Asian monsoon: links to solar changes and north Atlantic climate. Science, 308(5723), 854-857.

Webster, P.J. 1987. The variable and interactive monsoon. In Fein, J.S. and P.L. Stephens, eds. Monsoons. New York, J. Wiley and Sons.

Webster, P.J. and 6 others. 1998. Monsoons: processes, predictability, and the prospects for prediction. J. Geophys. Res., 103(C7), 14,451-14,510.

Weiss, H. and 6 others. 1993. The genesis and collapse of third millennium north Mesopotamian civilization. Science, 261(5124), 995-1003.

Yanai, M., C. Li and Z. Song. 1992. Seasonal heating of the Tibetan Plateau and its effects on the evolution of the Asian summer monsoon. J. Meteorol. Soc. Jpn, 70. 319-351.

Yao, T., L.G. Thompson, E. Mosley-Thompson, Z. Yang, X. Zhang and P. Lin. 1996. Climatological significance of $\delta^{18} \mathrm{O}$ in north Tibetan ice cores. J. Geophys. Res., 101(D23), 29,531-29,538.

Zagorodnov, V., L.G. Thompson, P. Ginot and V. Mikhalenko. 2005. Intermediate-depth ice coring of high-altitude and polar glaciers with a lightweight drilling system. J. Glaciol., 51(174), 491-501. 